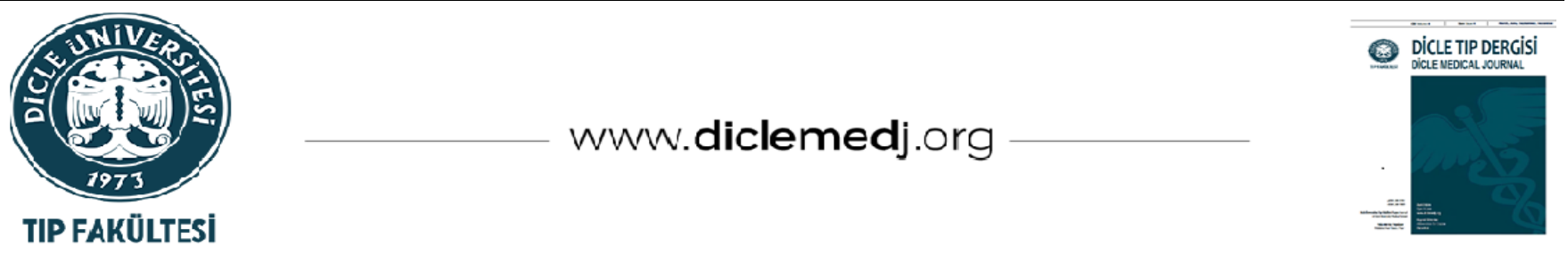

Case Report / Olgu Sunumu

\title{
A Rare Cause of Hydronephrosis: Retrocaval ureter
}

\author{
Mehmet Aktas ${ }^{D}$ 1, Mansur Daggülli ${ }^{i}{ }_{1}$ \\ 1 Dicle University Faculty of Medicine, Department of Urology, Diyarbakır, Turkey
}

Received: 10.03.2021; Revised: 04.05.2021; Accepted: 10.05.2021

\begin{abstract}
Retrocaval ureter is a rare congenital anomaly that can cause hydroureteronephrosis. The right ureter winds posterior to the inferior vena cava and then continues to cours anteriorly due to abnormal embryogenesis of vena cava. Retrocaval ureter is seen mostly on the right side except patients with situs inversus. Although retrocaval ureter is a congenital disease, patients become symptomatic during the third or fourth decade of their lives. Flank pain, hematuria, upper tract urinary infections and urolithiasis are the symptoms can be seen. Ultrasound can show the dilation of the kidney but it is far from accurate diagnosis. Retrocaval ureter is diagnosed with intravenous pyelography (IVP), computed tomography urography (CTU) and magnetic resonance urography (MRU). Mild hydronephrosis with good excretory times can be followed without surgical intervention. But severe hydronephrosis with symptoms should be corrected with surgery. The surgical treatment involves excision of the retrocaval part of the ureter then bringing it anterior to the vena cava followed by ureteroureteral or ureteropelvic anastomosis. Open, laparoscopic and robotic surgeries are the different treatment modalities. Transperitoneal and retroperitoneal approaches are different options for the surgery. In this paper we report a retrocaval ureter case managed with laparoscopic ureteroureterostomy.
\end{abstract}

Keywords: Retrocaval ureter, minimal invasive treatment, ureteroureterostomy

\section{Nadir bir Hidronefroz nedeni: Retrokaval üreter}

\section{Öz}

Retrokaval üreter hidroüreteronefroza neden olabilen nadir bir konjenital anomalidir. Vena kavanın anormal embriyogenezi nedeniyle sağ üreter vena cava inferiorun arkasından dönmekte ve sonrasında önünde devam etmektedir. Retrokaval üreter, situs inversuslu hastalar dışında çoğunlukla sağ tarafta görülmektedir. Retrokaval üreter konjenital bir hastalık olmasına rağmen hastalar hayatlarının üçüncü ve dördüncü dekatlarında semptomatik hale gelmektedirler. Yan ağrısı, hematüri, üst üriner sistem enfeksiyonları ve ürolitiazis görülebilen semptomlardır. Ultrason böbrekteki dilatasyonu göstermekte fakat kesin tanıyı koymaktan uzaktır. Retrokaval üreter tanısı; intravenöz pyelografi (IVP), bilgisayarlı tomografi ürografi (BTÜ) ve magnetik rezonans ürografi (MRÜ) ile konulmaktadır. İyi boşaltım zamanlı hafif hidronefrozlar cerrahi müdahale olmaksızın takip edilebilirler. Fakat semptomatik ciddi hidronefrozlar cerrahi ile düzeltilmelidir. Cerrahi tedavi; üreterin retrokaval parçasının kesildikten sonra vena cava önüne getirilmesi ve üreteroüreteral veya üreteropelvik anostomozunu gerektirmektedir. Açı, laparoskopik ve robotik cerrahiler değişik tedavi modaliteleridir. Transperitoneal ve retroperitoneal yaklaşımlar cerrahi için değişik seçeneklerdir. Bu yazımızda laparoskopik üreteroüreterostomi yapılarak tedavi edilen bir retrokaval üreter olgusunu sunmaktayı.

Anahtar kelimeler: Retrokaval üreter, minimal invazif tedavi, üreteroüreterostomi.

\section{DOI: 10.5798/dicletip.944407}

Correspondence / Yazışma Adresi: Mehmet Aktas, Dicle University Faculty of Medicine, Department of Urology, Diyarbakır, Turkey e-mail: drmaktas24@gmail.com 


\section{INTRODUCTION}

Retrocaval ureter is one of the rare reason causing hydronephrosis but it is usually asymptomatic during childhood. It becomes symptomatic in the third and fourth decade of life. Retrocaval ureter is found almost 3 times more often in men than in women and the prevelance is approximately $0.13 \%{ }^{1}$.

Retrocaval ureter is an embryological anomaly during the development of inferior vena cava. The theory is that right posterior cardinal vein persists anterior to the ureter and results in retrocaval ureter or preureter vena cava which causes obstruction in ureter and eventually hydronephrosis in the kidney. The ureter winds posteriorly to the vena cava and courses between the vena cava and aorta then continues to course anteriorly ${ }^{2}$. Retrocaval ureter is almost always seen on the right side and left retrocaval ureter is even rarer. It usually accompanies situs inversus ${ }^{3}$. Bilateral retrocaval ureter is the most rare form according to the current literature ${ }^{4}$.

There are two types of retrocaval ureter according to level where the ureter winds the vena cava ${ }^{5}$. Type 1 , also called low loop ureter, is more likely to deviate medially of middle ureteric segment and the ureter is usually obstructed. In type 2, which is also called high loop, the ureter winds the vena cava at the level of the uretero-pelvic junction or above $i^{2}$.

The symptoms are related to the degree of obstruction. Flank pain, hematuria, upper tract urinary infections and urolithiasis can be seen in this disease. Flank pain is the most common symptom and can vary from a dull, intermittent to acute and persistent ${ }^{2}$.

Herein we present a 25 years old male patient who suffers from right flank pain because of RCU and underwent transperitoneal laparoscopic ureteroureterostomy without complication.

\section{CASE REPORT}

A 25 years old male patient was presented with history of intermittent right side flank pain for 5 years which got worse in the last two months. Except for tenderness in his right flank region there was no significant sign neither in his physical examination nor in laboratuary tests. His abdominal ultrasound revealed grade 2 hydronephrosis with dilation of the proximal ureter. Computed tomography showed hydronephrosis in the right kidney with suspicion of retrocaval ureter (Figure 1,a). For further investigation intravenous pleyography was done which revealed classical 'fishhook' deformity (Figure 1,b).

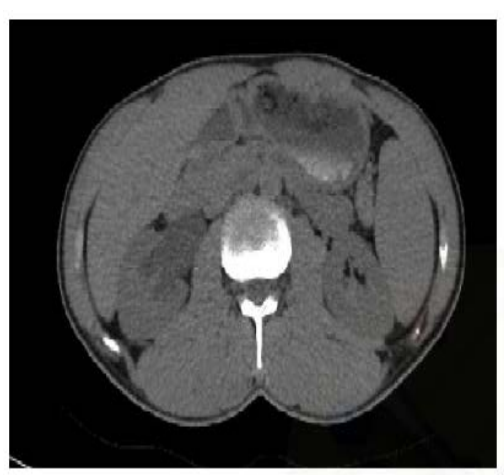

Figure 1,a

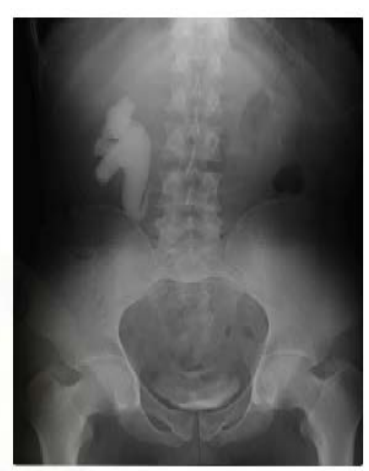

Figure $1, b$
Figure 1: Radiological Images

a. Computed Tomography shows grade 2 hydronephrosis of the right kidney b. Fishhook deformity in intravenous pyelography

Tc-99m

mercaptoacetyltriglycine(MAG3) scintigraphy was performed to understand the presence and severity of the obstruction. Clearence half time (T1/2) was 7 minutes for the left kidney and 15,7 minutes for the right kidney. Renal uptake was \%45,8 for the left kidney and \%54,1 for the right kidney (Figure 2,a). 


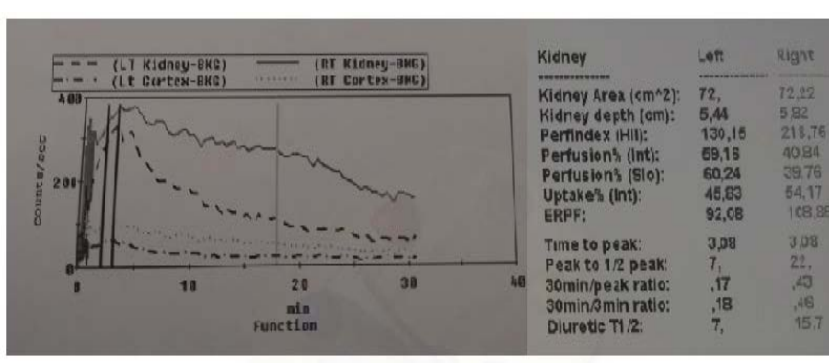

Figure 2

Figure 2: Scintigraphy Image

a. Tc-99m MAG3 scintigraphy shows delayed excretion of the right kidney

After obtaining informed consent, the patient was admitted to our clinic in order to correct this deformity with surgical repair.

\section{Surgical Technique}

Under general anesthesia, the patient was placed in lithotomy position. Routin cystoscopy was done and right ureter was visualised with retrograde pyelography (Figure 3,a).

We inserted a sensor guidewire to the right ureter for easier finding of the ureter intraoperatively. After inserting the foley catheter, the patient was placed in a modified flank position. First, a $10 \mathrm{~mm}$ port was placed one $\mathrm{cm}$ laterally to the umblicus and served as the camera port. Other $10 \mathrm{~mm}$ port was placed middle of the first port and right costal margin at the level of midclavicular line. The last port was placed between the umblicus and the anterosuperior iliac spine. Afterwards, the right ascending colon was dissected and reflected to reach the retroperitoneum. With the use of blunt dissection, renal pelvis and dilated proximal ureter were identified. By the help of a guidewire, the ureter was followed from dilated side to non-dilated side (Figure 3,b).

The distal ureter was then dissected carefully and the atretic part of it excised. After repositioning of the distal ureter to the anterior side of the vena cava inferior, spatulation was done and with $4 / 0$ poliglactin the suturization of posterior wall was completed. At this part we inserted 14-gauge intravenous cannula and guidewire was taken out with forceps. We inserted the double J catheter via 14-gauge intravenous cannula and removed guidewire gently. After the suturization of the anterior wall, the ureteroureterostomy was completed (Figure 3,c).

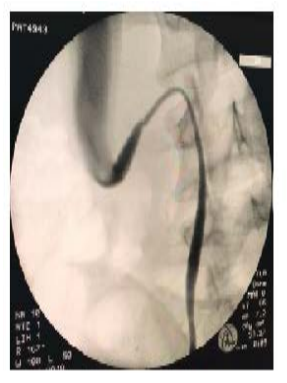

Figure 3a

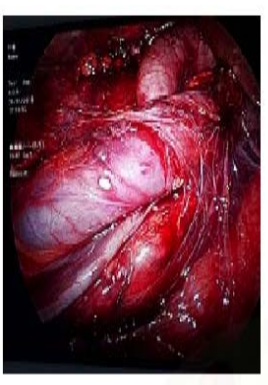

Flogure 3,

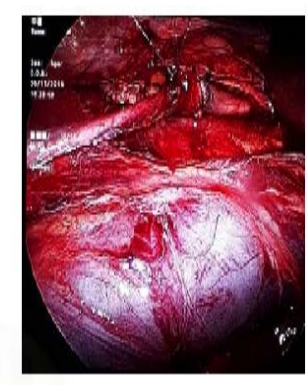

Figure 30
Figure 3: Surgery Images

a. Retrograde pyelography image b. Ureter's position which courses behind the vena cava inferior c. Anostomosis line and ureter's new position

Total operative time was 145 minutes of which the anostomosis part took 35 minutes with minimal blood loss. The patient was discharged on the third day. The double J stent was removed after 4 weeks. The patient was symptom-free in his follow up.

\section{DISCUSSION}

Retrocaval ureter was first described by Hochstetter in 18932. Since then its pathophysiology and treatment have been well described. It is one of the rare reason for hydronephrosis due to an adynamic segment of the ureter or compression by the psoas muscle. It should be emphasized that many cases are asymptomatic and only discovered incidentally during imaging for other reasons.

Although it usually becomes symptomatic during third or fourth's decade of the patient's life there have been symptomatic cases during childhood even in newborns ${ }^{6}$.

Asymptomatic patients with mild hydronephrosis can be followed without surgery until it becomes symptomatic or increase in the degree of hydronephrosis ${ }^{7}$. Yen et al. reported in their study that patients without symptoms and good excretory function 
on renogram can be followed with watchfull waiting8.

Renal colic, haematuria, increasing in the degree of hydronephrosis and deterioration of renal function in scintigraphy are the indications for the surgery ${ }^{8}$. Our patient wasn't suitable for watchfull waiting because of right flank pain and delayed exretion in Tc-99m mercaptoacetyltriglycine (MAG3) scintigraphy. Therefore surgical intervation was needed.

The surgical treatment is to correct ureter's position from posterior to anterior vena cava. Although open surgery was described as the gold standart treatment, today minimal invasive treatment became more favorable option because of it's shorter hospitalisation, less analgesic requirements and quicker convalescense. Laparoscopic transperitoneal, laparoscopic retroperitoneal and robotic assisted ureteroureterostomy or ureteropyelostomy are the different treatment modalities ${ }^{9-11}$.

In 1994, Baba et al. performed first laparoscopic correction of retrocaval ureter and they resected $5 \mathrm{~cm}$ of postcaval segment ${ }^{12}$. The operation time took 560 minutes due to lack of experience for laparoscopy and intracorporeal knotting.

Laparoscopic treatment can be done either by a transperitoneal or a retroperitoneal approach. Both ways have pros and cons. The advantage of retroperitoneal approach is direct access to urinary tract, shorter operation time and need to colon mobilisation ${ }^{9}$. On the other hand intracorporeal suturing and knotting become harder due to the lack of sufficient space. Ricciardulli et al. performed retroperineoscopic uretereureterostomy for 27 patients with RCU. They concluded that retroperineal approach is favorable approach for retrocaval ureter and also any kind of kidney surgery 9 . The advantage of the transperitoneal approach is that it has more space for suturing, being familiar with the anatomy and closing peritoneum and Gerota's fascia on to the anostomosis can reduce urine spillage $^{10}$. Ding et al. performed pure transperitoneal laparoscopic approach for 9 patients with RCU. They concluded that transperitoneal approach for RCU has an excellent outcome ${ }^{13}$. In our case, we chose transperitoneal approach because it allows the surgeon to suture and knot easily. In our opinion, another advantage of transperitoneal approach is being familiar with the anatomy from other urological surgeries.

The retrocaval segment of ureter can be excised if it seems adynamic. In 2006, Simfoorosh et al. reported that ureter relocation and anostomosis can be done without excision of the ureter behind the cava ${ }^{14}$. Also Harrech et al. didn't excise the ureter without any complication ${ }^{10}$. They also stated that with preserving the ureter, anostomosis can be done without high tension. But according to another study, the ureter just behind the vena cava is usually atretic and therefore should be excised ${ }^{9}$. They also stated that tension free anostomosis is mandatory. In our opinion, the retrocaval segment of ureter must be checked carefully during operation whether it looks atretic or not. After that excision can be decided.

Some authors prefer retrograde double J stent placement ${ }^{10}$. But we preferred antegrad route after complete suturing of the posterior wall. By using PICA technique, antegrad double J stent placement becomes easier ${ }^{15}$. no

Retrocaval ureter is a rare entity that urologists can encounter in their daily practise. Minimal invasive treatment is a feasible way to correct the ureter's positon from posterior to anterior of the vena cava. It has an excellent results with shorter hospitalization, less analgesic requirements and much smaller incision. Therefore, no matter which approach is being 
chosen, laparoscopy should be the gold standart for the treatment of RCU.

Ethics Committee Approval: Informed consent statement: Informed written consent was obtained from the patient for publication of this report and any accompanying images.

\section{REFERENCES}

1. Hostiuc S, Rusu MC, Negoi I, Grigoriu M, Hostiuc M. Retrocaval ureter: a meta-analysis of prevalence. Surg Radiol Anat. 2019 Nov; 41: 1377-82.

2. Abdessater M, El Khoury R, Elias S, et al. Diagnosis and laparoscopic management of retrocaval ureter: A review of the literature and our case series. International Journal of Surgery Case Reports. 2019; 59: 165-75.

3. Thirugnanasambandam V, Nayak P, Mossadeq A. Left retrocaval ureter without situs inversus or inferior venacava duplication. Indian J Urol. 2015 Dec; 31: 372-3.

4. Chou CT, Yang AD, Hong YC, Wu HK. Bilateral retrocaval ureters with IVC duplication. Abdom Imaging. 2006 Oct; 31: 596-7.

5. Bateson EM, Atkinson D. Circumcaval ureter: a new classification. Clin Radiol. 1969 Apr; 20: 173-7.

6. Bassiouny IE, Abbas TO, Mosleh A. Retrocaval ureter: a report on two neonates. Annals of Pediatric Surgery. 2013 Jan; 9: 40-4.

7. Ahmed M, Alhassan A, Sadiq M, et al. Variable presentation of retrocaval ureter: Report of four cases and review of literature. Niger Postgrad Med J. 2017; 24: 126.

8. Yen JM, Lee LS, Cheng CWS. Conservative management of retrocaval Ureter: A case series. International Journal of Surgery Case Reports. 2015; 15: 93-5.
Declaration of Conflicting Interests: The authors declare that they have no conflict of interest.

Financial Disclosure: No financial support was received.

9. Ricciardulli S, Ding Q, Zhang X, et al. (2015) Retroperitoneal Laparoscopic Approach for Retrocaval Ureter: Our Experience on 27 Cases. J Urol Res 2: 1033.

10. El Harrech Y, Ghoundale O, Kasmaoui EH, Touiti D. Transperitoneal Laparoscopic Pyelopyelostomy for Retrocaval Ureter without Excision of the Retrocaval Segment: Experience on Three Cases. Advances in Urology. 2016; 2016: 1-4.

11. Alkhudair WK, Seyam R, Al Zahrani, et al. Robotic uretero-ureterostomy of the retrocaval ureter without excision of the retrocaval segment. cuaj. 2012 Apr 17; 6: 38-41.

12. Baba S, Oya M, Miyahara M, Deguchi N, Tazaki H. Laparoscopic surgical correction of circumcaval ureter. Urology. 1994 Jul; 44: 122-6.

13. Ding G-Q, Xu L-W, Li X, et al. Pure transperitoneal laparoscopic correction of retrocaval ureter. Chin Med J (Engl). 2012 Jul;125: 2382-5.

14. Simforoosh N, Nouri-Mahdavi K, Tabibi A. Laparoscopic Pyelopyelostomy for Retrocaval Ureter Without Excision of the Retrocaval Segment: First Report of 6 Cases. Journal of Urology. 2006 Jun; 175: 2166-9.

15. Penbegul N, Atar M, Alan C, Bozkurt Y, Hatipoglu NK. A very easy technique of stenting for laparoscopic pyeloplasty: penbegul intravenous cannula (PICA) technique. Int braz j urol. 2019 Jan; 45: $179-82$. 